\title{
Efficacy of various seed protectants against Callosobruchus chinensis (L.) on cowpea (Vigna unguiculata L.) under storage condition
}

MAMTA DEVI CHOUDHARY*, T. M. BHARPODA, SUSHMA DEB AND SUMAN CHOUDHARY

Department of Entomology, B. A. College of Agriculture, Anand Agricultural University, ANAND (GUJARAT) INDIA

\section{ARITCLE INFO}

Received : 10.04 .2017

Revised : 15.08 .2017

Accepted : 27.08.2017

\section{KEY WORDS :}

Plant oils, Botanical leaf powders, Insecticides, Seed protectants, Cowpea, Callosobruchus chinensis Linnaeus
*Corresponding author:

Email : mmtchoudhary233@gmail.com

\begin{abstract}
Investigations were carried out at Department of Entomology, B. A. College Agriculture, Anand Agricultural University, Anand, Gujarat (India) during 2011-12 for the evaluation of plant oils, botanical leaf powders as well as synthetic insecticides as seed protectants against Callosobruchus chinensis Linnaeus on stored cowpea. Cowpea seeds treated with castor, Neem and pongam oil @ 1\% (v/w) recorded significantly higher adult mortality ( $\geq 57 \%$ ) of $C$. chinensis during storage period of 6 months with higher half-life values (about 2.5 months), higher gross persistency (4707 to 3597), lower population growth (3.87 to 5.36 adult emergence) and lower per cent loss in germination (19.45 to $22.36 \%$ ). Among the various leaf powders; Neem, eucalyptus and Tulsi @ 2\% recorded higher per cent adult mortality (> 43\%), higher half-life (about 3 months) and higher gross persistence $(\geq 2909)$ values, lower number of adult emergence $(\leq 2.67)$ and higher germination count $(\geq 70 \%)$ and were found to be more effective. Among synthetic insecticides; deltamethrin $2.8 \mathrm{EC}$, cypermethrin $10 \mathrm{EC}$, spinosad $45 \mathrm{SC}$ and fenvalerate 20 EC @ 4 ppm were significantly more effective against $C$. chinensis and recorded significantly higher mortality (> 71\%) with higher half-life values (3 to 8 months), higher persistency $(\geq 5121)$ and lower number of adult emergence $(\leq 2.63)$. The same insecticides also exhibited lower per cent loss (10.16 to $18.66 \%)$ in germination of cowpea seeds.
\end{abstract}

How to view point the article : Choudhary, Mamta Devi, Bharpoda, T.M., Deb, Sushma and Choudhary, Suman (2017). Efficacy of various seed protectants against Callosobruchus chinensis (L.) on cowpea (Vigna unguiculata L.) under storage condition. Internat. J. Plant Protec., 10(2) : 303-310, DOI : 10.15740/HAS/IJPP/10.2/303-310. 